\title{
Bronchoscopy with Biopsy
}

National Cancer Institute

\section{Source}

National Cancer Institute. Bronchoscopy with Biopsy. NCI Thesaurus. Code C51638.

Removal of bronchial tissue for microscopic examination, using an endoscope. 